\title{
Nutrient, chlorophyll and zooplankton seasonal variations on the southern coast of a subtropical saline lake (Mar Chiquita, Córdoba, Argentina)
}

\author{
Alberto Pilati $^{1 *}$, Marcela Castellino ${ }^{2}$ and Enrique H. Bucher ${ }^{3}$ \\ 1 Facultad de Ciencias Exactas y Naturales, Universidad Nacional de La Pampa, Uruguay 151, 6300 Santa Rosa, La Pampa, \\ Argentina \\ 2 Instituto de Diversidad y Ecología Animal (CONICET-UNC) and Facultad de Ciencias Exactas Físicas y Naturales, Universidad \\ Nacional de Córdoba, Av. Vélez Sarsfield 299, CP 5000, Córdoba, Argentina \\ 3 Instituto de Diversidad y Ecología Animal (CONICET-UNC) and Centro de Zoología Aplicada, Facultad de Ciencias Exactas \\ Físicas y Naturales, Universidad Nacional de Córdoba, Rondeau 798, CP 5000, Córdoba, Argentina
}

Received 22 December 2015; Accepted 9 April 2016

\begin{abstract}
Mar Chiquita is the largest salt lake in South America. Because of its rich and diverse biodiversity, it has been designated a world site of the Ramsar Convention on Wetlands. Despite its importance, its limnological characteristics are poorly documented. Here we report a baseline assessment of the seasonal variations of several limnological parameters on the southern coast of the lake. Samples were obtained at two lake sites (pelagic and coastal) and an additional site in the Laguna del Plata estuary lagoon. We found that Mar Chiquita is a well-mixed eutrophic shallow lake with significant spatial and seasonal variations in its limnological parameters. Of particular relevance are the spring turnover and the clear water phase in summer, being characterized by nutrient peaks (total nitrogen, total phosphorus $(\mathrm{P})$ and soluble reactive $\mathrm{P}$ ) in early spring, followed by peaks in zooplankton and ammonia in late spring and summer, together with a decrease in chlorophyll and $\mathrm{pH}$. These events appear related to seasonal variations in water temperature and the shallowness of the lake that allows strong biochemical interactions with sediments. Correlations among the studied parameters indicate a significant role of zooplankton (particularly the brine shrimp) in controlling phytoplankton abundance. Laguna del Plata has typical estuary characteristics, including high variability in salt concentrations (13-63 g. $\left.\mathrm{L}^{-1}\right)$, high nutrient levels $\left(0.48 \mathrm{mg} \mathrm{P.L^{-1 }}\right)$ (hypereutrophic) and higher phytoplankton biomass than the main lake. Mar Chiquita characteristics show interesting similarities with those recorded in the Great Salt Lake in the USA.
\end{abstract}

Key words: saline shallow lake / Brine shrimp / Ramsar site / Nutrient dynamics / Estuary lagoon

\section{Introduction}

Mar Chiquita is the largest salt lake in South America, with an area that has ranged between 2000 and $6000 \mathrm{~km}^{2}$. Given its rich biodiversity, particularly of birds, Mar Chiquita is a provincial Reserve, and a site of international importance according to the Ramsar Convention on Wetlands (Bucher, 2006).

The lake has remained largely unknown in the English-language scientific literature, to the point of not being included in Hammer's review of the saline lakes of the world (Hammer, 1986). In recent years a growing research effort has resulted in new publications on different aspects of the lake's physical and biological characteristics, which have been summarized in Bucher

\footnotetext{
*Corresponding author: apilati@exactas.unlpam.edu.ar
}

(2006). However, information on the lake's limnology is still scarce. After a comprehensive, pioneering study conducted by Seckt (1945), little progress has been made, particularly in terms of understanding the functional aspects of this lake ecosystem.

The marked spatial and temporal variability that characterizes Mar Chiquita presents a major challenge for limnological studies (Bucher, 2006). Spatial variability relates to the lake's size and the presence of deltas and estuary lagoons derived from the three tributary rivers. Still more importantly, drastic oscillations in water level and salinity are frequent, which is to be expected in a terminal lake under a semi-arid rainfall regime. Moreover, the fact that in 2004 Mar Chiquita reached the highest level over its whole geological history in the last 50000 years (Piovano et al., 2006), suggests the possible influence of a global climate change trend. 
Understanding lake dynamics therefore requires an initial sustained and comprehensive monitoring effort, aimed at covering both spatial and temporal sources of variability as much as possible. In this paper, we take a first step in this direction by providing a description of the present limnological characteristics of Mar Chiquita, focused on the southern coast and the estuary lagoon of one of the main tributary rivers. Our specific objective was to describe seasonal variations at the selected sites (pelagic, coastal and Laguna del Plata) in terms of the following parameters: salinity, $\mathrm{pH}$, water transparency, organic suspended solids, chlorophyll, zooplankton biomass, total nitrogen (TN), ammonia, total phosphorus (TP), soluble reactive phosphorus (SRP) and the TN:TP molar ratio.

\section{Methods}

\section{Study area}

Mar Chiquita is a shallow, saline lake of tectonic origin located in the vast plains of central Argentina (from $29^{\circ} 48^{\prime} \mathrm{S}$ to $30^{\circ} 59^{\prime} \mathrm{S}$ and from $62^{\circ} 10^{\prime} \mathrm{W}$ to $63^{\circ} 23^{\prime} \mathrm{W}$ ), at an altitude of about $62 \mathrm{~m}$ a.s.l. The lake is permanent, with an area that has fluctuated historically between 2000 and $6000 \mathrm{~km}^{2}$ (Fig. 1) (Bucher, 2006). Most of the lake area is very shallow, with maximum depth ranging between 2 and $11 \mathrm{~m}$ according to water level (Bucher, 2006).

Mar Chiquita is surrounded by a semi-arid region dominated by woodland forests and agricultural land. Crop production and cattle raising are the predominant land-use forms in the region. The lake is the final collector of a basin of about $40000 \mathrm{~km}^{2}$, with three main tributaries: the Primero, Segundo and Dulce Rivers. The Dulce River comes from the north, providing about $80 \%$ of the lake's incoming flow. The Primero and Segundo Rivers come from the south, and provide the remaining $20 \%$ of the incoming flow (Fig. 1).

Water chemistry of the lake is characterized by dominance of sodium chloride $(78 \%)$, followed by sodium sulfate $(17 \%)$, calcium sulfate $(2 \%)$ and magnesium sulfate $(2 \%)$. According to the level, salinity has ranged between 300 g. $\mathrm{L}^{-1}$ in dry periods and $25 \mathrm{~g} . \mathrm{L}^{-1}$ in wet years (Bucher and Bucher, 2006). During our study the water level decreased $0.35 \mathrm{~m}$ and salinity increased about 10 g. $\mathrm{L}^{-1}$ in the pelagic area.

The lake plankton varies according to the salinity level of the lake. In general terms, the phytoplankton is dominated by diatoms, followed by green algae and cyanobacteria (Bucher and Abril, 2006). The zooplankton also changes with water salinity levels. The brine shrimp (Artemia franciscana) becomes increasingly abundant with salinities above 50 g.L $\mathrm{L}^{-1}$ (Bucher and Abril, 2006; Curto, 2006).

Fish have been absent from the lake, with the only exception of the 1982-2009 wet period when water salinity decreased to between 25 and 50 g. $\mathrm{L}^{-1}$. This drop in salinity allowed invasion by the silverside (Odontesthes bonariensis) from the tributary rivers, which reached high population levels that allowed commercial exploitation (Bucher and Etchegoin, 2006).

In addition, Mar Chiquita has abundant bird fauna, including both resident and migratory species, particularly shorebirds and three flamingo species. Given the lake's importance for bird conservation, this site is a Córdoba provincial Reserve and was also nominated a Ramsar Site by the Ramsar Convention on Wetlands.

The southern lake area is relatively open and uniform, with the exception of the $18 \mathrm{~km}^{2}$ Rio Primero estuarine river-mouth lagoon (Laguna del Plata) (Fig. 1). The lagoon's limnological conditions are subject to frequent and drastic variations, depending on fluctuations in the incoming river flow and the lake water level. As the lagoon connects to the main lake through a shallow and narrow passage, it probably determines a significant water retention time, and occasionally, depending on the lake's level, may reach total isolation from the main lake.

\section{Sampling design}

We selected three sampling sites representative of different habitats of key importance in terms of understanding the functional dynamics of the lake. Two of them were in the main lake (pelagic and coastal), and the remaining in Laguna del Plata (Fig. 1). The pelagic site was located at about $4 \mathrm{~km}$ north of the southern coast $\left(30^{\circ} 53^{\prime} 33.4^{\prime \prime} \mathrm{S}, 62^{\circ} 42^{\prime} 0.66^{\prime \prime} \mathrm{W}\right)$. The coastal site was on the shoreline in Miramar town (the only urban center in Mar Chiquita) (30 54'62" S; 62 $\left.40^{\prime} 45^{\prime \prime} \mathrm{W}\right)$. The Laguna del Plata sampling site coordinates are $30^{\circ} 56^{\prime} 06^{\prime \prime} \mathrm{S} ; 62^{\circ} 53^{\prime} 19.34^{\prime \prime} \mathrm{W}$. All samples were taken at the water surface level on four dates, hereafter referred to by the name of the season when samples were taken: (1) July 22, 2010 (winter); (2) September 14, 2010 (early spring); (3) November 14, 2010 (late spring); and (4) February 15, 2011 (summer). The depth at each sampling site was $5.2 \mathrm{~m}$ for the pelagic site and $0.8 \mathrm{~m}$ for the coastal and Laguna del Plata sites.

The following parameters were measured at each site and on each date: salinity, $\mathrm{pH}$, dissolved oxygen (DO), Secchi disc water transparency (SDT), organic suspended solids (OSS), chlorophyll- $a$ (Chl), zooplankton biomass (Zoop), TN, TP, ammonia $\left(\mathrm{NH}_{4}\right)$ and SRP. Inorganic suspended solids were not estimated due to the interfering effect of salt accumulation on the filter. Prior to this study (2008-2009), we measured the lake water temperature on an hourly basis at $2.5 \mathrm{~m}$ depth during a whole year (HOBO data logger, Onset Computer Corporation Bourne, MA, USA), which provides a reference database for this study.

At each site (pelagic, coastal and Laguna del Plata), we collected two samples from points that were at least $300 \mathrm{~m}$ apart to ensure independence between samples. The sample size was established based on pilot sampling, using salinity and chlorophyll concentrations as proxies of dissolved and particulate limnological parameters, and considering an allowable error of the sample mean of $20 \%$ (Prepas, 1984). In addition, temperature and oxygen profiles were measured in each sampling event at the 

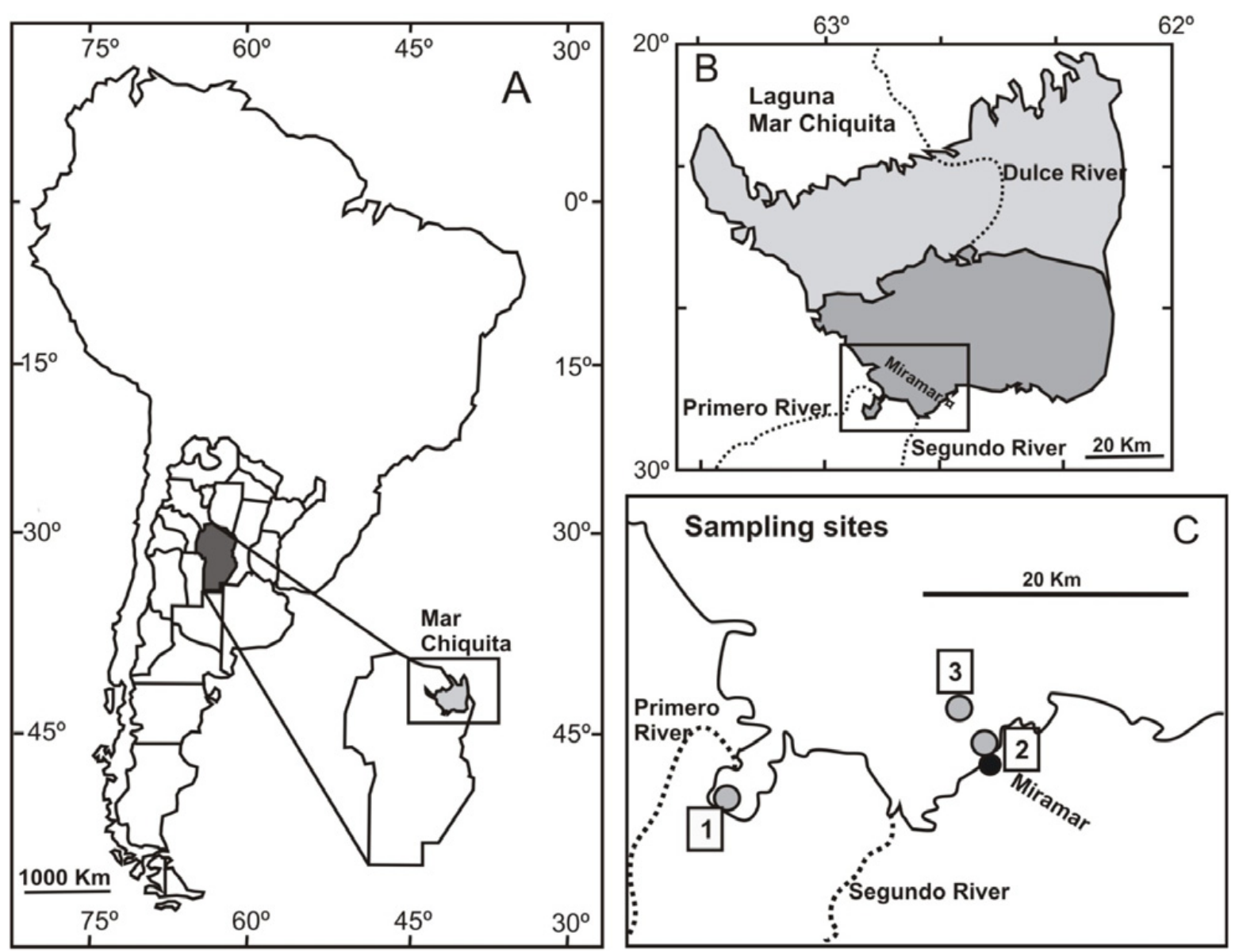

Fig. 1. (A) Map showing the provinces of Argentina. The lower right inset shows the location of laguna Mar Chiquita in the province of Córdoba. (B) Area occupied by Mar Chiquita at low (dark gray) and high level periods (light gray). Watersheds of tributary rivers are not completely shown. (C) Sampling sites on the southern coast of Mar Chiquita: (1) Laguna del Plata, (2) Coastal (Miramar shoreline), (3) Pelagic site.

pelagic site using a YSI model 50 oxygen meter. A salinity profile at the pelagic site was recorded in February 2011 only. All measurements were taken at about 11:00 AM.

\section{Analytical procedure}

Salinity was measured in situ with a 0-100 ppt refractometer (Vee Gee Model A366ATC; SchmidtHaensch, Berlin), and $\mathrm{pH}$ was determined in the laboratory with a YSI EcoSense pH100A meter. DO was quantified with a YSI meter model 55 calibrated at a salinity of $33 \mathrm{~g} . \mathrm{L}^{-1}$. Actual DO concentrations were estimated for higher salinities according to Sherwood et al. (1991) and, therefore, they must be considered relative. Secchi disc water transparency (SDT) was measured in situ with a $0.20-\mathrm{m}$ diameter Secchi disc. OSS were determined gravimetrically by filtering zooplankton-free water (previously filtered with a $60 \mu \mathrm{m}$ mesh) through a GF/F glass fiber filter. OSS were estimated by the difference between the filter dried at $60{ }^{\circ} \mathrm{C}$ for $24 \mathrm{~h}$ and the same filter ashed at $550^{\circ} \mathrm{C}$ for $1 \mathrm{~h}$ (EPA, 1993).

Chlorophyll- $a$ (Chl) concentrations were measured with a Turner Designs Aquafluor fluorometer after cold extractions $\left(\sim 18 \mathrm{~h}\right.$ at $\left.5^{\circ} \mathrm{C}\right)$ with acetone (Strickland and Parsons, 1972) and corrected for phaeopigments (Arar and Collins, 1997). Zooplankton biomass (Zoop) was assessed by filtering $30 \mathrm{~L}$ with a $63-\mu \mathrm{m}$ mesh net. Samples were preserved with formalin in situ. Total zooplankton biomass was immediately measured once in the laboratory by filtering a subsample on a pre-weighted glass fiber filter dried at $60^{\circ} \mathrm{C}$ for $24 \mathrm{~h}$. Based on McCauley (1984), we assumed that weight loss was non-significant after a short period $(<5 \mathrm{~h})$ of formalin preservation. We did not identify plankton species in the collected material, except $A$. franciscana, which according to visual inspection was by far the dominant component in terms of biomass.

TN and TP were assessed using unfiltered water samples that were digested with potassium persulfate (Ebina et al., 1983) and analyzed as nitrate with the cadmium reduction method, and SRP with the ascorbic method, respectively (APHA, 1992), using a Metrolab 1700 spectrophotometer. Dissolved nutrients were analyzed in water samples filtered with GF/F glass fiber filters. SRP and ammonia were measured using the ascorbic acid and the phenate methods, respectively (APHA, 1992), with a Metrolab 1700 spectrophotometer. 
As many limnological variables lacked homoscedasticity and because of the low number of replicates $(n=2)$ for each date $(n=4)$, parameter correlation among variables $(N=8)$ was explored using Spearman rank-order correlation (Zar, 1996) with PAST 3.06 (Hammer et al., 2001).

To explore the degree of eutrophication in Mar Chiquita, we used the method developed by Carlson (1977). The trophic state index (TSI) was used only for comparative purposes within the lake as these indexes were developed for freshwater lakes, whose physical, chemical and biological characteristics are different from salt lakes.

\section{Results}

\section{Pelagic and coastal sites}

The annual water temperature variations at the pelagic site follow a well-defined seasonal pattern, with a mild winter and warm summer. Winter (July) mean temperature was $10.7^{\circ} \mathrm{C}$, whereas in summer (February) average temperature reached $24.1^{\circ} \mathrm{C}$. By early spring (September) water temperature steadily rises, and remains above $20^{\circ} \mathrm{C}$ for 6 months (Fig. 2).

Salinity in the pelagic sites increased slightly $(10.7 \%)$ along the study period, from 58 to 65 g.L ${ }^{-1}$. The lake salinity profile was measured only in the summer and was 65 g.L $\mathrm{L}^{-1}$ along the entire profile. Temperature profiles indicated uniform temperature values from the surface down to $4 \mathrm{~m}$ in depth in winter and summer, whereas in early spring bottom temperatures $\left(4 \mathrm{~m}\right.$ deep) were $2.5^{\circ} \mathrm{C}$ lower than at the surface (Fig. 3(A)).

Oxygen concentration at the pelagic site was similar along the entire profile in winter, showing a moderate decrease with depth in early and late spring, and reached a minimal bottom concentration of $2.2 \mathrm{mg} . \mathrm{L}^{-1}$ in summer (Fig. 3(B)). On this last sampling date, the sampled material had a strong sulfide smell, indicating anoxic conditions.

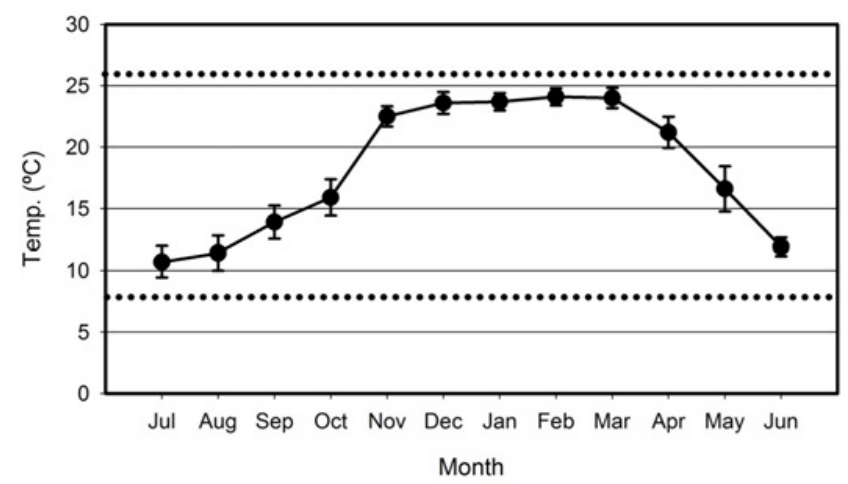

Fig. 2. Mar Chiquita water temperature $\left({ }^{\circ} \mathrm{C}\right)$. Annual variation at the Pelagic site (maximum depth of $5.2 \mathrm{~m}$ ) taken with a data logger at $2.5 \mathrm{~m}$ below surface (2008-2009). Dotted lines indicate the absolute minimum and maximum temperatures recorded.
During the study, Mar Chiquita's water level decreased, whereas salinity increased and $\mathrm{pH}$ decreased in early and late spring, stabilizing in summer (Fig. 4). Value ranges of the studied parameters are shown in Table 1, and their seasonal variations in Figure 4.

Regarding nutrients, ammonium peaked in late spring, while TN peaked in early spring, and slowly decreased afterwards. At both sites, TP and SRP had a significant peak in early spring. Particularly, during this peak, SRP reached concentrations up to 12 times higher than those observed at the beginning of the study. Thus, higher variations were observed in SRP than TP (Table 1). The TN:TP (molar) ratio was higher during the cold season (peaking in winter at the pelagic site and in early spring at the coastal site).

At both sites, the TN:TP molar ratio was always higher than the 20:1 threshold, which according to Dzialowski et al. (2005) indicates the breaking point between $\mathrm{N}$ and $\mathrm{P}$ limitation, indicating some degree of co-limitation or $\mathrm{P}$ limitation of the phytoplankton.

Water transparency had similar values during the study except in summer when it showed a substantial increase. The higher variability observed in summer (Fig. 4) was caused by strong mixing in the coastal area due to strong winds during sampling.

Surface water was well oxygenated at both sites, always above $5.6 \mathrm{mg} . \mathrm{L}^{-1}$ (Table 1). OSS values remained stable during the study (Table 1). Chlorophyll $a$ showed a marked decrease from initial values in winter to a minimum in late spring, recovering moderately in summer (Fig. 4). Inversely, zooplankton biomass (mainly composed of brine shrimp at all development stages) showed a well-defined peak in late spring, which was higher in the pelagic site (Fig. 4).

As to interactions between the studied parameters at the main lake sites, salinity was negatively correlated with $\mathrm{pH}(r=-0.788, P=0.0008)$ and positively (marginally) with ammonium $(r=0.485, P=0.058)$. Also, salinity was positively correlated with zooplankton biomass $(r=0.728$, $P=0.002)$ and negatively correlated with chlorophyll- $a$ (as a proxy of phytoplankton biomass) $(r=-0.703$, $P=0.003)$. Zooplankton biomass was positively correlated with ammonia $(r=0.706, P=0.003)$ but negatively correlated with chlorophyll- $a(r=-0.865, P<0.0001)$, $\mathrm{pH} \quad(r=-0.916, \quad P<0.0001)$ and TN $(r=-0.659$, $P=0.007)$. There was also a strong negative correlation between OSS and water transparency $(r=-0.619$, $P=0.010)$. For the pelagic and coastal sites, the average TSI based on $P$ was $86.3( \pm 5.0)$ and $87.2( \pm 3.3)$, based on chlorophyll $67.8( \pm 4.9)$ and $68.3( \pm 5.6)$, and based on water transparency $70.1( \pm 2.3)$ and $72.0( \pm 1.1)$, respectively.

\section{The Laguna del Plata}

Salinity in the brackish waters of Laguna del Plata decreased along the study period, particularly in summer (Fig. 4) when it dropped to 13 g. $\mathrm{L}^{-1}$ due to an increase in 

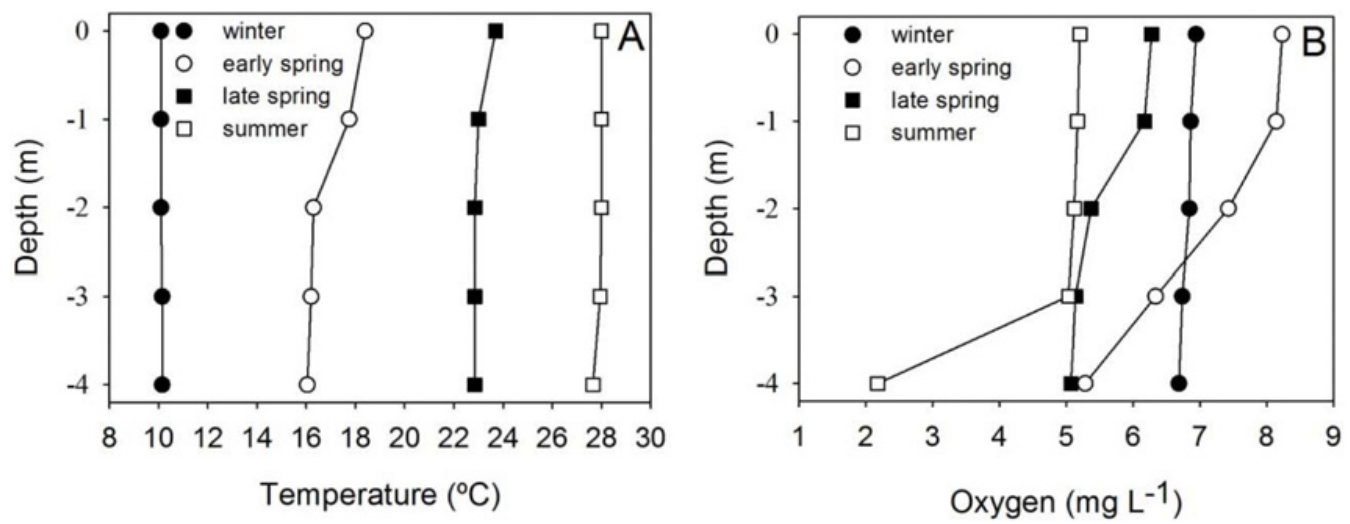

Fig. 3. Mar Chiquita temperature (A) and DO profiles (B) at the Pelagic site taken on July 22, 2010 (winter), September 14, 2010 (early spring), November 14, 2010 (late spring) and February 15, 2011 (summer).

fresh water inflow from the Primero River. However, $\mathrm{pH}$ remained relatively stable (Table 1) showing a slight decrease, much less pronounced than in the main lake (Fig. 4, Table 1). Daytime oxygen surface concentration was about twice the values found in the main lake.

Regarding nutrients, ammonium concentrations remained stable in winter and early spring, decreasing to very low values in summer (Fig. 4). TN showed a similar pattern to that in the lake, peaking in early spring and declining in late spring and summer. SRP also followed the same pattern, with a peak in early spring. TP values remained quite stable, well above those of the main lake (Table 1, Fig. 4). TN:TP molar ratio variations also followed the main lake, with a peak in early spring and lower values in late spring and summer. In all seasons, TN:TP ratios were lower than those at the lake sites, because of higher TP concentrations in Laguna del Plata.

Water transparency in Laguna del Plata was lower than in the main lake at all dates (Fig. 4), reaching a minimum of $0.19 \mathrm{~m}$ in late spring (Table 1). OSS increased steadily throughout the study, in all cases with values well above those of the main lake.

Chlorophyll- $a$ was much higher in Laguna del Plata than in the main lake, steadily increasing from winter to summer, whereas zooplankton biomass declined from the winter value down to very low values during the rest of the study (Fig. 4).

The average TSI at Laguna del Plata was $92.9( \pm 1.7)$ based on P, $82.3( \pm 3.4)$ based on chlorophyll, and 92.9 $( \pm 1.7)$ based on water transparency, with much less variability than in the main lake (Table 1).

\section{Discussion}

\section{Pelagic sites: characteristics and functional interactions}

Our data indicate that the Mar Chiquita is a eutrophichypereutrophic lake. The TSI based on $\mathrm{P}$ and water transparency for the pelagic and coastal sites were always higher than 70 , indicating a clear hypereutrophic condi- tion. The TSI based on chlorophyll, on the other hand, ranged mostly in the eutrophic zone (TSI 50-70) consistent with a eutrophic condition, bordering hypertrophy. Our results also show a high similarity between the characteristics and dynamics of the pelagic and coastal sites.

Of particular significance is the marked spring turnover that is reflected in nutrient peaks (TN, TP and SRP) in early spring, followed by peaks in zooplankton and ammonia in late spring, together with a decrease in chlorophyll and $\mathrm{pH}$ (Fig. 4). This spring turnover may be interpreted as an initial increase in TN, TP and SRP due to decomposition of lake sediments as a result of the marked rise in water temperature in the warm season. According to our 2008-2009 measurements, water temperature ranges from a mean of $8.1{ }^{\circ} \mathrm{C}$ in winter (July) to $23.7^{\circ} \mathrm{C}$ in summer (February) (Fig. 2). This increase is also found for water temperature at the bottom of the lake (Fig. 3(A)). After the early spring peak, a decrease in TP concentrations (Fig. 4) suggests the presence of algal sedimentation processes or grazing losses due to the increase in brine shrimp at that time.

Clearly, this spring peak cannot be attributed to a "spring turnover" in the classic sense of limnology, given the shallowness of the lake and the minimal vertical stratification during the summer and winter (Fig. 3(A)).The lake's shallowness, together with the already mentioned significant seasonal rise in water temperature (Fig. 2), may lead to higher mineralization rates and nutrient release from lake sediment (Scheffer, 2004). Organic matter decomposition may also explain, at least in part, a decrease in $\mathrm{pH}$ due to carbon dioxide production from aerobic decomposition (Wetzel, 2001).

A contributing factor to the spring peak that deserves consideration is the nutrient load coming from the tributary rivers. However, this process may be secondary in early spring, because at this time (end of the dry season) the incoming flow is at its lowest level (Bucher, 2006).

The simultaneous occurrence in late spring of a marked fall in chlorophyll and peak values in zooplankton, together with the year-long negative correlation between zooplankton and chlorophyll biomass, suggests a strong grazing pressure by zooplankton (particularly the brine 
MAR CHIQUITA
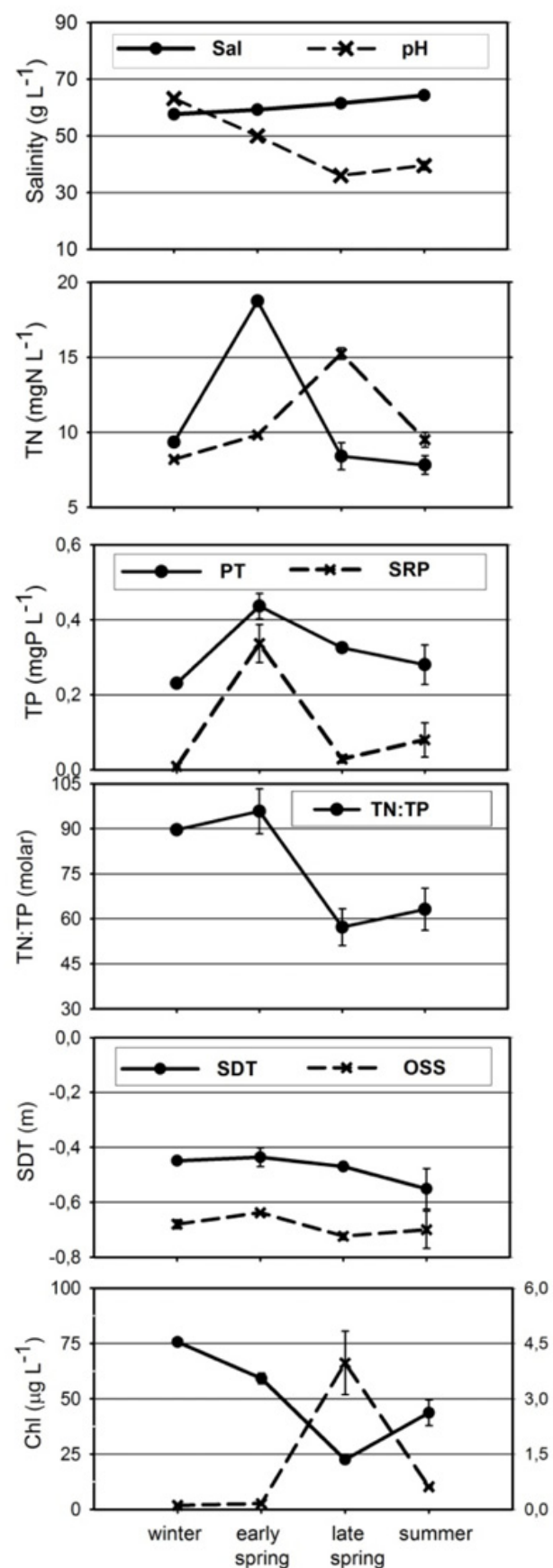

LAGUNA DEL PLATA
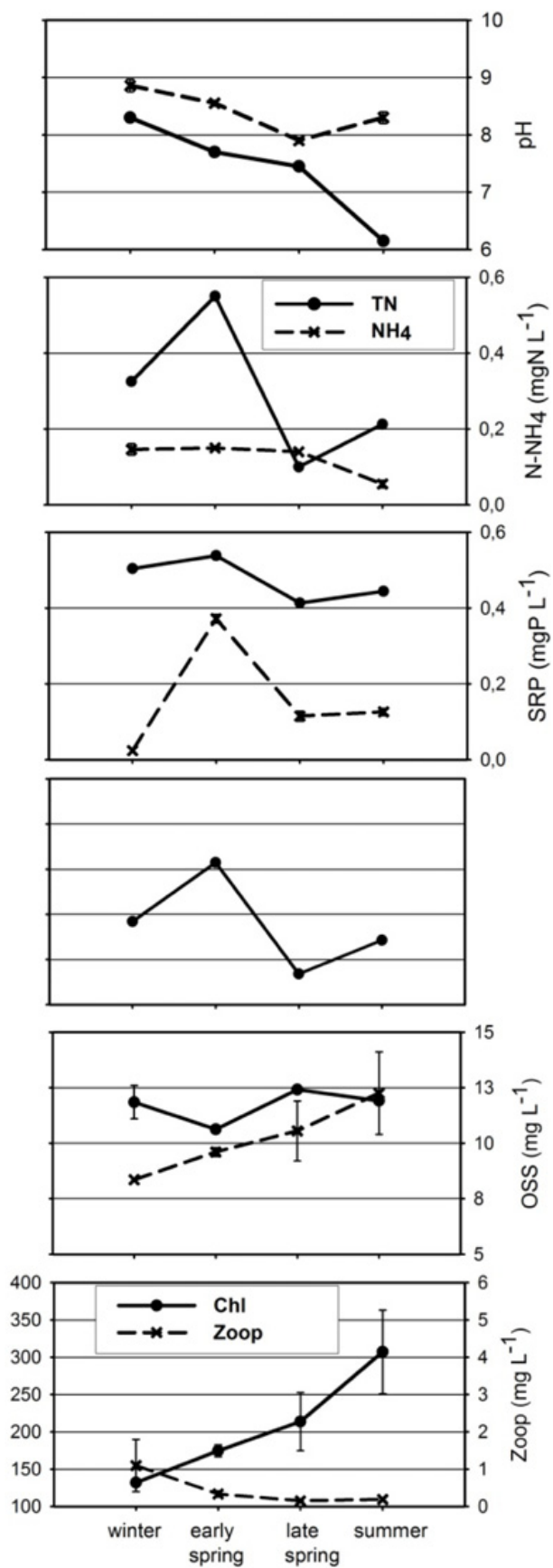

Fig. 4. Temporal variations in limnologic parameters in Mar Chiquita for Main Lake area (Pelagic and Coastal combined) and Laguna del Plata. Salinity (g. $\left.\mathrm{L}^{-1}\right)$, pH, TN (mg N.L ${ }^{-1}$ ), ammonium (N-NH (molar), SDT (m), OSS (mg. $\left.\mathrm{L}^{-1}\right)$, chlorophyll a (Chl, in $\left.\mu \mathrm{g} . \mathrm{L}^{-1}\right)$ and zooplankton dry weight biomass $\left(\right.$ Zoop, mg. $\left.{ }^{-1}\right)$. Argentina. Note that different scales were used for chlorophyll in Laguna del Plata. Error bars indicate the standard deviation $(n=4$ for Coastal and Pelagic combined, and $n=2$ for Laguna del Plata). In some cases, error bars are too small to be visible.

shrimp). This assumption is also supported by the finding that brine shrimp may ingest about $50-94 \%$ of the algae biomass available in the Great Salt Lake water column (Wurtsbaugh, 1992).

In turn, the observed high correlation between zooplankton abundance and ammonia concentration may be related to metabolic excretion by zooplankton.
This effect has already been reported by Belovsky et al. (2011) in the Great Salt Lake, where the authors state that brine shrimp "increase photic zone DIN through their excretion (ammonia)". Another alternative condition for ammonia production relates to the presence of anoxic conditions due to increased microbial activity in the water-sediment mat (Scheffer, 2004). In addition, 
Table 1. Extreme values observed in the main limnological parameters for the pelagic and coastal sites combined and for Laguna del Plata.

\begin{tabular}{|c|c|c|}
\hline & Pelagic/Coastal & Laguna del Plata \\
\hline$\overline{\text { Level (m a.s.l.) }}$ & $68.45-68.17$ & - \\
\hline Salinity (g. $\left.\mathrm{L}^{-1}\right)$ & $57.0-65.0$ & $13.5-64.1$ \\
\hline $\mathrm{pH}$ & $7.3-8.7$ & $7.8-8.9$ \\
\hline Water transparency (m) & $0.24-0.72$ & $0.19-0.36$ \\
\hline Surface dissolved $\mathrm{O}_{2}\left(\mathrm{mg} . \mathrm{L}^{-1}\right)$ & $5.6-9.8$ & $10.7-18.5$ \\
\hline OSS $\left(\mathrm{mg} . \mathrm{L}^{-1}\right)$ & $5.4-7.3$ & $8.1-11.9$ \\
\hline $\mathrm{TSI}_{\mathrm{P}}$ & $82.4-92.9$ & $91.0-94.8$ \\
\hline $\mathrm{TSI}_{\mathrm{Chl}}$ & $60.2-73.1$ & $78.5-86.5$ \\
\hline $\mathrm{TSI}_{\mathrm{SDT}}$ & $66.8-73.1$ & $80.1-82.7$ \\
\hline Ammonium (mg N.L ${ }^{-1}$ ) & $0.12-0.45$ & $0.05-0.16$ \\
\hline Soluble reactive $\mathrm{P}\left(\mathrm{mg}\right.$ P. $\left.\mathrm{L}^{-1}\right)$ & $0.008-0.750$ & $0.021-0.710$ \\
\hline $\mathrm{TN}\left(\mathrm{mg} \mathrm{N} . \mathrm{L}^{-1}\right)$ & $7.2-18.8$ & $7.5-18.8$ \\
\hline TP $\left(\mathrm{mg} \mathrm{P} \mathrm{L}^{-1}\right)$ & $0.23-0.47$ & $0.41-0.54$ \\
\hline TN:TP (molar) & $51-103$ & $51-77$ \\
\hline Chlorophyll $a\left(\mu \mathrm{g} . \mathrm{L}^{-1}\right)$ & $23-77$ & $130-382$ \\
\hline Zooplankton (mg.L $\left.\mathrm{L}^{-1}\right)$ & $0.05-6.37$ & $0.12-1.64$ \\
\hline
\end{tabular}

Note: TSI indicates the Trophic State Index based on different limnological parameters: P: phosphorus, Chl: chlorophyll, and SDT: Secchi disc transparency.

zooplankton biomass (mainly brine shrimp) was also negatively correlated with $\mathrm{pH}$, probably because of increased respiration by the growing brine shrimp biomass added to sediment decomposition, without being compensated by the decreasing phytoplankton biomass (Fig. 4). Alternatively, Greenwald and Hurlbert (1993) also found that increasing salinities reduced the $\mathrm{pH}$ by altering the dissociation-association equilibrium of bicarbonates, which was also observed during our study (Fig. 4).

During summer, the observed record value of water transparency (SDT) at the pelagic site and to a lesser extent at the coastal site appears similar to the clear-water phase that often occurs in freshwater lake plankton at the end of the spring (see Fig. 4). According to Scheffer (2004), this scenario is typical of eutrophic lakes, and also appears more likely in lakes with few or no planktivorous fish, allowing substantial growth of planktivorous invertebrates (Scheffer, 2004). Both conditions applied to Mar Chiquita during our study period. Thus, heavy grazing by brine shrimp might control the phytoplankton community as reported by Wurtsbaugh (1992) in the Great Salt Lake. In addition, the strong negative correlation found between SDT and OSS, together with a decline in TN, ammonia and TP suggest nutrient depletion as an alternative (or additional) influencing factor.

\section{Laguna del Plata}

Laguna del Plata shows typical lagoon characteristics, including high variability in salt concentration, high nutrient levels and high productivity (Kjerfve, 1994). This lagoon has a higher eutrophic condition than the main lake, with higher $\mathrm{N}, \mathrm{P}$ and much higher chlorophyll concentrations. The three TSIs analyzed were always higher than 70, indicating a clear hypereutrophic condition all year long. In situ $\mathrm{N}$ fixation is likely to contribute to the $\mathrm{N}$ load of this lagoon as well as in the main lake, considering that $\mathrm{N}$-fixing cyanobacteria are dominant at both sites (Bucher and Abril, 2006). Wurtsbaugh and Marcarelli (2006) found that chlorophyll levels in the Great Salt Lake increased by up to $500 \%$ when salinity was $<70$ g. $\mathrm{L}^{-1}$, and the $\mathrm{N}_{2}$-fixing cyanobacterium Nodularia spumigena dominated the community. This species has also been reported for both Laguna del Plata and the main lake (Bucher and Abril, 2006).

A preliminary analysis of the Laguna del Plata phytoplankton community in November 2010 showed that Nodularia sp. population had an estimated biomass of $42 \%$ of the total community (salinity $=39$ g. $\mathrm{L}^{-1}$ ), which confirms its high $\mathrm{N}$-fixing potential in the lagoon (A. Pilati, unpublished data). Despite potential $\mathrm{N}$ fixation, the lower summer TN:TP ratio found in Laguna del Plata than in the main lake is to be expected in eutrophic lakes with very high $\mathrm{P}$ availability (Scheffer, 2004). Further evidence of the high degree of eutrophication in Laguna del Plata comes from previous field observations of anoxic conditions at the bottom of the lake, high $\mathrm{H}_{2} \mathrm{~S}$ production, and occasional massive fish mortality events, particularly during summer months (E.H. Bucher, unpublished data).

The lack of a significant zooplankton peak in Laguna del Plata, as compared with the main lake, may explain the much higher chlorophyll levels found in Laguna del Plata. A possible explanation for this contrasting situation is the presence of the silverside fish (Odonthestes bonariensis), an obligate zooplankton feeder, in Laguna del Plata, which contrasts with total fish absence in the main lake at the time of this study. Occurrence of silverside in Laguna del Plata but not in the main lake is consistent with the fact that salinity at Laguna del Plata was below the upper 60 g. $\mathrm{L}^{-1}$ tolerance limit for the silverside recorded in Mar Chiquita, and also by permanent occurrence of the fish in the Primero River (Bucher and Etchegoin, 2006). 
It is likely that the Primero River may influence the P load of Laguna del Plata, given the predominant agriculture and cattle raising land use in the area, as confirmed by significant levels of agriculture-derived contaminants found in Laguna del Plata and the Mar Chiquita lake (Ballesteros et al., 2014). In occasional samples taken from this river we found concentrations of about $0.8 \mathrm{mg} \mathrm{P.L}{ }^{-1}$. In addition, Oroná et al. (2010) found high SRP concentrations in the Primero River reaching up to $1 \mathrm{mg}$ P.L ${ }^{-1}$.

\section{Mar Chiquita compared with other saline lakes}

Comparison of Mar Chiquita's characteristics with other salt lakes is restricted by the limited number of lakes for which information on limnological parameters is available.

Mar Chiquita nutrient levels were characteristic for salt lakes of endorheic regions. According to Hammer (1986), terminal saline lakes with no outlet tend to have higher $\mathrm{P}$ concentrations than non-saline lakes. However, various $\mathrm{N}$ fractions have similar ranges of concentrations to those of non-saline waters and these are likely related to productivity levels.

Our TP and TN measurements were slightly higher than those reported for the Salton Sea (Setmire, 2000), the Dead Sea (Stiller and Nissenbaum, 1999), or the Aral Sea (Friedrich and Oberhänsli, 2004). Mar Chiquita TN and TP values are similar to those reported by Wurtsbaugh and Smith Berry (1990) for the Great Salt Lake (USA)

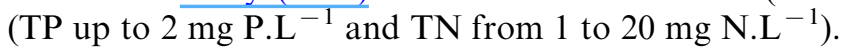

Regarding dissolved nutrients, SRP concentrations were slightly higher than most of the salt lakes, but fell within the reported range for the Great Salt Lake (0.2-0.4 mg P.L ${ }^{-1}$; Belovsky et al., 2011) and the lake's hypereutrophic Farmington Bay $\left(0.006-0.370 \mathrm{mg} \mathrm{P.L}{ }^{-1}\right.$; Wurtsbaugh and Marcarelli, 2006). Otherwise, ammonia concentrations fell within the range for most of the reported salt lakes. Ammonia values are generally low in lakes that are well aerated but high values have been reported under anoxic conditions (Hammer, 1986).

Chlorophyll concentrations in Mar Chiquita were similar to Salton lake (Setmire, 2000) and some areas of the Great Salt Lake (Belovsky et al., 2011). Marcarelli et al. (2006) reported chlorophyll values as high as $350 \mu \mathrm{g} . \mathrm{L}^{-1}$ in Farmington Bay, Great Salt Lake, which are very similar to the concentrations found in Laguna del Plata.

Clearly, similarities between Mar Chiquita's pelagic and coastal sites and the Great Salt Lake pelagic area of Gilbert Bay (Great Salt Lake, USA), as well as between the highly eutrophic Laguna del Plata in Mar Chiquita and Farmington Bay in Great Salt Lake provide interesting opportunities for comparative studies.

Regarding Argentina, where salt lakes are numerous and widespread, a detailed comparative analysis is restricted by the very scarce and fragmented information available on the annual cycle of nutrient dynamics and other limnological parameters (see Quirós, 1988, 1990; Quirós and Drago, 1999 for an overview of these systems).

\section{Conclusions}

Based on nutrient concentration, Mar Chiquita may be considered eutrophic, a condition frequently found in saline lakes. Despite Mar Chiquita being a subtropical salt lake, we found significant seasonal variations in its limnological parameters and a relevant spring turnover and a clear water phase during the summer. These events appear related to seasonal variations in water temperature and the shallowness of the lake that allows strong chemical interaction with sediment. Correlations among the studied parameters indicate the significant role of zooplankton (particularly brine shrimp) in controlling the phytoplankton biomass.

The Laguna del Plata has typical estuary characteristics, including high variability in salt concentration, high nutrient levels (hypereutrophic) and higher phytoplankton biomass than the main lake.

Given that our study refers to a specific water and salinity level of the lake, more research will be needed to understand the functional changes that may emerge under the wide range of water level variations that can be expected in a terminal lake like Mar Chiquita. These multi-state conditions may have great influence on the biodiversity of the reserve.

Acknowledgements. A.P. was supported by a grant from Universidad de La Pampa, Facultad de Ciencias Exactas y Naturales (Project no. 231/2011) and Fondo para la Investigación Científica y Tecnológica (FONCYT) through PICT-PRH 2008-00301. E.H.B. received international support from the US Fish and Wildlife Service, Division of International Conservation (Project no. 96200-9-6215). We would like to thank the Municipalidad de Miramar, Mar Chiquita, for providing infrastructure support during the field work period.

\section{References}

American Public Health Association (APHA), 1999. Standard Methods for the Examination of Water and Wastewater (20th edn), Washington, DC.

Arar E.J. and Collins G.B., 1997. In vitro determination of chlorophyll a and phaeophytin a in marine and freshwater phytoplankton by fluorescence. Method 445.0. In: USEPA, Methods for the Determination of Chemical Substances in Marine and Estuarine Environmental Samples, Environmental Protection Agency (EPA), Cincinnati, OH.

Ballesteros M.L., Miglioranza K.S.B., Gonzalez M., Fillmannc G., Wunderlin D.A. and Bistoni M.A., 2014. Multimatrix measurement of persistent organic pollutants in Mar Chiquita, a continental saline shallow lake. Sci. Total Environ., 490, 73-80.

Belovsky G.E., Stephens D., Perschon C., Birdsey P., Paul D., Naftz D., Baskin R., Larson C., Mellison C., Luft J., 
Mosley R., Mahon H., Van Leeuwen J. and Allen D.V., 2011. The Great Salt Lake Ecosystem (Utah, USA): long term data and a structural equation approach. Ecosphere, 2, $1-40$.

Bucher E.H. (ed.), 2006. Bañados del río Dulce y laguna Mar Chiquita (Córdoba, Argentina), Academia Nacional de Ciencias, Córdoba, Argentina.

Bucher E.H. and Abril A.B., 2006. Limnología Biológica. In: Bucher E.H. (ed.), Bañados del rio Dulce y laguna Mar Chiquita (Córdoba, Argentina), Academia Nacional de Ciencias, Córdoba, Argentina, 117-137.

Bucher E.H. and Bucher A.E., 2006. Limnología física y química. In: Bucher E.H. (ed.), Bañados del rio Dulce y laguna Mar Chiquita (Córdoba, Argentina), Academia Nacional de Ciencias, Córdoba, Argentina, 79-101.

Bucher E.H. and Etchegoin M., 2006. El pejerrey como recurso. In: Bucher E.H. (ed.). Bañados del rio Dulce y laguna Mar Chiquita (Córdoba, Argentina), Academia Nacional de Ciencias, Córdoba, Argentina, 201-217.

Carlson R.E., 1977. A trophic state index for lakes. Limnol. Oceanogr., 22, 361-369.

Curto E.D., 2006. Artemia, el camarón de la sal. In: Bucher E.H. (ed.), Bañados del rio Dulce y laguna Mar Chiquita (Córdoba, Argentina), Academia Nacional de Ciencias, Córdoba, Argentina, 161-171.

Dzialowski A.R., Wang S., Lim N., Spotss W.W. and Huggins D.G. 2005. Nutrient limitation of phytoplankton growth in central plains reservoirs, USA. J. Plank. Res., 27, 587-595.

Ebina J., Tsutsui T. and Shirai T., 1983. Simultaneous determination of total nitrogen and total phosphorus in water using peroxodisulfate oxidation. Water Res., 17, 1721-1726.

Environmental Protection Agency (EPA), 1993. ESS Method 340.2: Total Suspended Solids, Mass Balance (Dried at 103-105 \&\#730;C) Volatile Suspended Solids (Ignited at 550 \&\#730;C), Accessed online 20/04/2011, http://www.epa.gov/ glnpo/lmmb/methods/methd340.pdf.

Greenwald G.M. and Hurlbert S.H., 1993. Microcosm analysis of salinity effects on coastal lagoon plankton assemblages. Hydrobiologia, 267, 307-335.

Hammer Ø., Harper D. and Ryan P., 2001. PAST: paleontological statistics software package for education and data analysis. Palaeontol. Electron., 4, 1-9.

Hammer U.T., 1986. Saline Lake Ecosystems of the World, Dr. W. Junk Publishers, Dordrecht, Springer, 616 p.

Kjerfve B., 1994. Coastal Lagoon Processes, Elsevier Science Publishers, New York, $531 \mathrm{p}$.

Marcarelli A.M., Wurstbaugh W.A. and Griset O., 2006. Salinity controls phytoplankton response to nutrient enrichment in the Great Salt Lake, Utah, USA. Can. J. Fish. Aquat. Sci., 63, 2236-2248.

McCauley E., 1984. The estimation of the abundance and biomass of zooplankton in samples. In: Downing J.A. and F.H. Rigler (eds.), A Manual on Methods for the Assessment of Secondary Productivity in Fresh Waters, Backwell Science Publ., Oxford, 228-265.

Oroná C., Carranza P.M., Rodríguez M.I., Larrosa N., Pozzi C. and Rodríguez A., 2010. Evaluación Limnológica de la Laguna del Plata - Mar Chiquita, Córdoba. Ciencia, 5, 63-73.

Piovano E.L., Zanor G.A. and Ariztegui D. 2006. Historia geológica y registro climático. In: Bucher E.H. (ed.), Bañados del río Dulce y laguna Mar Chiquita (Córdoba, Argentina), Academia Nacional de Ciencias, Córdoba, Argentina, 37-55.

Prepas E.E., 1984. Some statistical methods for the design of experiments and the analysis of samples. In: Downing J.A. and Rigler F.H. (eds.), A Manual on Methods for the Assessment of Secondary Productivity in Fresh Waters, Backwell Science Publ., Oxford, 266-336.

Quirós R., 1988. Relationships between air temperature, depth, nutrients and chlorophyll in 103 Argentinian lakes. Verh. Int. Verein. Limnol., 23, 647-658.

Quirós R., 1990. Factors related to variance of residuals in chlorophyll - total phosphorous regressions in lakes and reservoirs of Argentina. Hydrobiologia, 200/201, $143-355$.

Quirós R. and Drago E., 1999. Lakes Reserv. Res. Manag., 4, 55-64.

Scheffer M., 2004. Ecology of Shallow Lakes. Population and Community Biology Series, Kluwer Academic Publishers, Dordrecht, The Netherlands.

Seckt H., 1945. Estudios hidrobiológicos hechos en la Mar Chiquita. Boletín de la Academia Nacional de Ciencias de Córdoba (Córdoba, Argentina), 37, 279-309.

Setmire J. (ed.), 2000. Eutrophic conditions at the Salton Sea. A topical paper from the Eutrophication Workshop convened at the University of California at Riverside, September 7-8, 2000. $21 \mathrm{p}$.

Sherwood J.E., Stagnitt F. and Kokkinn M.J., 1991. Dissolved oxygen concentrations in hypersaline waters. Limnol. Oceanogr., 36, 235-250.

Strickland J.D.H. and Parsons T.R., 1972. A Practical Handbook of Seawater Analysis (2nd edn), Fisheries Research Board of Canada, Vol. 167, Otawa.

Wetzel R.G., 2001. Limnology: Lake and River Ecosystems (3rd edn,), Academic Press, San Diego, California.

Wurtsbaugh W.A., 1992. Food-web modification by an invertebrate predator in the Great Salt Lake. Oecologia, 89, 168-175.

Wurtsbaugh W.A. and Marcarelli A., 2006. Eutrophication in Farmington Bay, Great Salt Lake, Utah 2005 Annual Report. Report to the Central Davis Sewer District, 90 p.

Wurtsbaugh W.A. and Smith Berry T., 1990. Cascading effects of decreased salinity on the plankton, chemistry, and physics of the Great Salt Lake (Utah). Can. J. Fish. Aquat. Sci., 47, 100-109.

Zar J.H., 1996. Biostatistical Analysis (3rd edn), Prentice-Hall, New Jersey, 662 p. 